\title{
Renal Regulation of Acid-Base Equilibrium during Chronic Administration of Mineral Acid
}

\author{
Rui C. De Sousa, John T. Harrington, Edmond S. Ricanati, \\ Joel W. Shelkrot, and William B. Schwartz \\ From the Department of Medicine, Tufts University School of Medicine, and \\ the Renal Laboratory, New England Medical Center Hospital, \\ Boston, Massachusetts 02111
}

\begin{abstract}
A B S T R A C T Previous studies in metabolic alkalosis have demonstrated that two factors are the prime determinants of acid excretion and bicarbonate reabsorption; first, the diversion to distal exchange sites of sodium previously reabsorbed in the proximal tubule and loop of Henle; and, second, a stimulus to sodium-cation exchange greater than that produced by a low-salt diet alone. In the present study we have examined the hypothesis that these two factors are also the prime determinants of acid excretion during the administration of mineral acid loads. To test this hypothesis, we have administered to dogs ingesting a low $\mathrm{NaCl}$ diet a daily dose of $7 \mathrm{meq} / \mathrm{kg}$ of $\mathrm{H}^{+}$with anions (chloride, sulfate, or nitrate) whose differing degrees of reabsorbability influence the speed and completeness with which each is delivered to the distal nephron with its accompanying $\mathrm{Na}^{+}$. After 2-3 wk of acid administration, and after an initial urinary loss of $\mathrm{Na}^{+}$and $\mathrm{K}^{+}$, the steady-state value for plasma $\left[\mathrm{HCO}_{3}{ }^{-}\right]$was $8.6 \mathrm{meq} /$ liter below control in the $\mathrm{HCl}$ group, 3.7 meq/liter below control in the $\mathrm{H}_{2} \mathrm{SO}$. group, and unchanged from control in the $\mathrm{HNO}_{3}$ group; all of these values were significantly different from each other.
\end{abstract}

We would propose the following explanation for our findings: when $\mathrm{HCl}$ is administered chronically, marked acidosis occurs because distal delivery of $\mathrm{Cl}^{-}$is restricted by the ease with which the $\mathrm{Cl}^{-}$can be reabsorbed in the proximal portions of the nephron. Only when $\mathrm{Cl}^{-}$retention produces sufficient hyperchloremia to insure delivery of $\mathrm{Na}^{+}$(previously reabsorbed in proximal tubule and loop of Henle) to the distal nephron in quantities equal to ingested $\mathrm{Cl}$ is this primary constraint removed. In the case of sulfuric and nitric acids, there

A preliminary report of this work was published in abstract form in J. Clin. Invest. 49: 40a (Abstr.). 1970.

Received for publication 9 July 1973 and in revised form 17 September 1973.

The Journal of Clinical Investigation Volume 53 February 1974.465-476 is no constraint on distal delivery, the nonreabsorbability of the administered anion causing prompt, total delivery of $\mathrm{Na}^{+}$to exchange sites in quantities equal to administered hydrogen. Thus, with $\mathrm{H}_{2} \mathrm{SO}_{4}$ and $\mathrm{HNO}_{3}$ the sole constraint on removal of the acid load is the inability of the distal exchange mechanism to conserve the $\mathrm{Na}^{+}$increment fully by means of $\mathrm{H}^{+}$exchange. Escape of $\mathrm{Na}^{+}$and $\mathrm{K}^{+}$into the urine and the resulting stimulus to $\mathrm{Na}^{+}-\mathrm{H}^{+}$exchange remove this constraint and are responsible for establishment of a new steady-state of acidbase equilibrium at plasma $\left[\mathrm{HCO}_{3}^{-}\right]$levels significantly higher than those seen with $\mathrm{HCl}$.

The feeding of $\mathrm{HCl}$ in the presence of a normal salt intake led to a degree of metabolic acidosis not significantly different from that seen in dogs ingesting a lowsalt diet. We suggest that the presence of dietary sodium at distal exchange sites did not enhance acid excretion because it is only after a loss of body sodium stores that sodium avidity is increased sufficiently to allow full removal of the acid load.

The present findings indicate that the fundamental factors controlling acid excretion and bicarbonate reabsorption in metabolic acidosis are closely similar to those operative in metabolic alkalosis.

\section{INTRODUCTION}

Available data provide little support for the hypothesis that renal acid excretion is regulated primarily by changes in systemic acid-base balance. In fact, a variety of experiments during the development and maintenance of metabolic alkalosis indicate that both acid excretion and bicarbonate reabsorption can be progressively augmented in the face of a rise in both plasma bicarbonate concentration and $\mathrm{pH}$ (1-3). An analysis of such situations indicates that the interplay of two factors accounts for the observed behavior; first, an increased 
TABLE I

Summary of Experimental Protocols

\begin{tabular}{cccc}
\hline \multirow{2}{*}{ Acid } & Dose of $\mathrm{H}^{+}$ & $\begin{array}{c}\text { Dose of } \\
\mathrm{NaCl}\end{array}$ & $\begin{array}{c}\text { Number of } \\
\text { studies }\end{array}$ \\
\hline \multirow{3}{*}{$\mathrm{HCl}$} & meq/kg/day & $m M / \mathrm{kg} /$ day & \\
& 7.0 & 3.0 & 7 \\
& 5.25 & 3.0 & 7 \\
& 3.5 & 3.0 & 6 \\
$\mathrm{H}_{2} \mathrm{SO}_{4}$ & 7.0 & 0 & 6 \\
$\mathrm{HNO}_{3}$ & 3.5 & 0 & 4 \\
& 7.0 & 0 & 7 \\
\end{tabular}

delivery to distal exchange sites of sodium previously reabsorbed in proximal portions of the nephron, and second, an initial loss of some portion of this sodium into the urine with a concomitant contraction of extracellular fluid volume and stimulus to sodium transport sufficient to produce full conservation of all additional "proximal" sodium diverted to exchange sites $(4,5)$.

The present studies were undertaken to explore the possibility that the mechanisms responsible for regulating acid excretion in metabolic alkalosis also control acid excretion in metabolic acidosis. To this purpose we have administered large hydrogen ion loads with anions that were either highly reabsorbable (chloride) or poorly reabsorbable (sulfate and nitrate) and have carried out detailed metabolic balance studies over several weeks. The data demonstrate notable differences in the response of plasma bicarbonate concentration and in electrolyte balance during long-term administration of the three acids to dogs ingesting a low-salt diet. These differences appear to be fully accounted for by the effect of the administered anion on delivery of proximal sodium loads to distal exchange sites. Animals given hydrochloric acid and a normal salt intake underwent virtually the identical reduction in plasma bicarbonate concentration as did those on a low-salt diet.

We conclude that in the dog the primary factors controlling the secretion of acid and reabsorption of bicarbonate in both metabolic acidosis and alkalosis are first, the rate of delivery of proximal sodium to the distal nephron. and second, the avidity of the distal exchange sites for sodium.

\section{METHODS}

Balance studies were carried out on 43 female mongrel dogs weighing between 11 and $23 \mathrm{~kg}$. Animals were utilized only if average control plasma $\left[\mathrm{HCO}_{3}^{-}\right]$was between 21.0 and $24.5 \mathrm{meq} / \mathrm{liter}$. After a control period of 4-9 days each animal was fed one of three mineral acids (hydrochloric, sulfuric, or nitric acid), in association with either a normal or low $\mathrm{NaCl}$ intake, until a new steady-state level of plasma $\left[\mathrm{HCO}_{3}{ }^{-}\right]$had been achieved. Seven combinations of anion, hydrogen load, and dose of sodium chloride were employed; these are specified in Table I.
Throughout the study each $\operatorname{dog}$ was fed $25 \mathrm{~g} / \mathrm{kg} / \mathrm{day}$ of a synthetic diet, the composition of which has been previously described (6). The intrinsic electrolyte content of the diet was approximately $1 \mathrm{meq}$ of sodium, $0.5 \mathrm{meq}$ of chloride, and $0.1 \mathrm{meq}$ of potassium/100 g. Each day, 2.5 $\mathrm{meq} / \mathrm{kg}$ of potassium as neutral potassium phosphate was added to the diet. The diet was mechanically blended with twice its weight of water and fed in one or two portions. Supplemental electrolytes and acid were added to the mechanically blended diet from stock solutions, the composition of which had been verified by direct analysis. Dogs that did not eat spontaneously were force-fed and those that vomited at any time were discarded.

Preliminary studies suggested that a steady state of acidbase balance was achieved within the first few days of hydrochloric acid administration but that with sulfuric and nitric acids a period of approximately 2 wk was required before a steady state was achieved. All nitric and sulfuric acid studies were therefore carried out for 21 days. The first ten $\mathrm{HCl}$ studies were also carried out for 21 days but when statistical analysis of these studies demonstrated that a steady state was achieved considerably earlier, the duration of the remaining studies with $\mathrm{HCl}$ was reduced to 15 days.

The details of the balance technique, calculations, and most of the analytical methods have been described previously $(7,8)$. Stool and urine nitrogens were determined by a manual or by an automated (9) Kjeldahl digestion method.

\section{RESULTS}

Unless otherwise specified, the term "significant" will be used to describe a difference that has a $P$ value of less than 0.01 .

Control plasma bicarbonate concentration. The mean control plasma $\left[\mathrm{HCO}_{3}{ }^{-}\right]$in the 20 animals ingesting $\mathrm{NaCl}$ was $22.0 \pm 0.2 \mathrm{meq} / \mathrm{liter}$ and in the 23 animals ingesting a low $\mathrm{NaCl}$ diet was $23.1 \pm 0.2$ meq/liter. This difference, though small, was significant. To facilitate comparisons between the low and normal $\mathrm{NaCl}$ groups, as well às to permit each of these animals to serve as its own control, we have expressed the change in plasma $\left[\mathrm{HCO}_{3}{ }^{-}\right]$from control to steady-state periods as delta values. No significant differences were noted in control plasma $\left[\mathrm{Na}^{+}\right],\left[\mathrm{K}^{+}\right]$, and $\left[\mathrm{Cl}^{+}\right]$among the groups.

Recovery of administered acid and accompanying anion. Table II shows for all groups the percentage of administered $\mathrm{H}^{+}$and accompanying anion recovered in the urine during the first 15 days of study. As is apparent, the recovery rates of administered hydrogen and anion were similar in all groups. The percentage of acid excreted after 15 days ranged between 81 and $93 \%$ of the load and the percentage of anion between 88 and $97 \% .^{1}$

${ }^{1}$ Because of a concern that the divalent anion sulfate might not be completely absorbed, we carried out analyses of stool aliquots for sulfate. These analyses revealed that the maximum fecal loss of sulfate during the first 15 days of acid feeding could not have exceeded $3 \%$ of the administered load. 


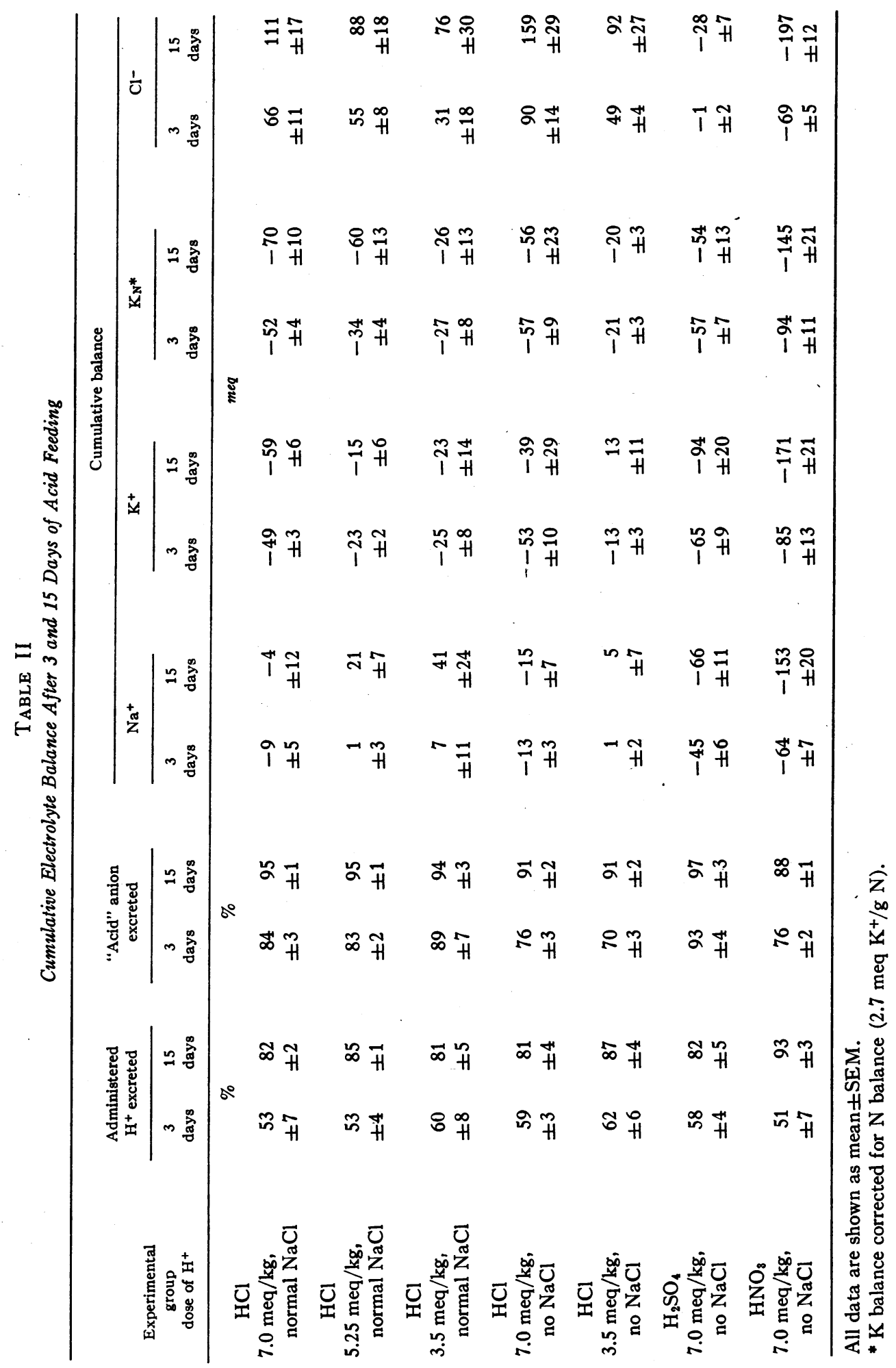


TABLE III

Plasma Composition during the Control and Steady-State Periods in Animals Receiving Mineral Acid

\begin{tabular}{|c|c|c|c|c|c|c|c|}
\hline $\begin{array}{l}\text { Experimental } \\
\text { group } \\
\text { dose of } \mathrm{H}^{+}\end{array}$ & Period & $\mathrm{HCO}_{3}-$ & $\mathrm{H}^{+}$ & $\mathrm{PaCO}_{2}$ & $\mathrm{Na}^{+}$ & $\mathrm{K}^{+}$ & $\mathrm{Cl}^{-}$ \\
\hline $\mathrm{HCl}$ & & meq/liter & neq/liter & $m m \mathrm{Hg}$ & meq/liter & meq, $\mathbf{q}_{\prime}^{\prime}$ iler & meq/liter \\
\hline $\begin{array}{l}7.0 \mathrm{meq} / \mathrm{kg} \\
\text { normal } \mathrm{NaCl}\end{array}$ & $\begin{array}{l}\text { Control } \\
\text { Exp. }\end{array}$ & $\begin{array}{l}22.2 \pm 0.2 \\
16.0 \pm 0.6\end{array}$ & $\begin{array}{l}43 \pm 0.3 \\
53 \pm 1.0\end{array}$ & $\begin{array}{l}39 \pm 0.4 \\
35 \pm 0.8\end{array}$ & $\begin{array}{l}147 \pm 0.2 \\
146 \pm 0.4\end{array}$ & $\begin{array}{l}3.8 \pm 0.1 \\
3.0 \pm 0.1\end{array}$ & $\begin{array}{l}112 \pm 0.9 \\
119 \pm 0.7\end{array}$ \\
\hline $\begin{array}{c}\mathrm{HCl} \\
5.25 \mathrm{meq} / \mathrm{kg}, \\
\text { normal } \mathrm{NaCl}\end{array}$ & $\begin{array}{l}\text { Control } \\
\text { Exp. }\end{array}$ & $\begin{array}{l}22.4 \pm 0.3 \\
17.6 \pm 0.5\end{array}$ & $\begin{array}{l}43 \pm 0.6 \\
49 \pm 0.8\end{array}$ & $\begin{array}{l}40 \pm 0.8 \\
36 \pm 1.0\end{array}$ & $\begin{array}{l}146 \pm 0.5 \\
147 \pm 0.5\end{array}$ & $\begin{array}{l}4.0 \pm 0.1 \\
3.5 \pm 0.1\end{array}$ & $\begin{array}{l}110 \pm 0.7 \\
116 \pm 0.7\end{array}$ \\
\hline $\begin{array}{c}\mathrm{HCl} \\
3.5 \mathrm{meq} / \mathrm{kg} \\
\text { normal } \mathrm{NaCl}\end{array}$ & $\begin{array}{l}\text { Control } \\
\text { Exp. }\end{array}$ & $\begin{array}{l}21.5 \pm 0.2 \\
18.3 \pm 0.5\end{array}$ & $\begin{array}{l}42 \pm 0.5 \\
46 \pm 0.8\end{array}$ & $\begin{array}{l}37 \pm 0.5 \\
35 \pm 0.7\end{array}$ & $\begin{array}{l}147 \pm 0.6 \\
148 \pm 0.5\end{array}$ & $\begin{array}{l}3.9 \pm 0.1 \\
3.7 \pm 0.1\end{array}$ & $\begin{array}{l}112 \pm 0.3 \\
116 \pm 0.6\end{array}$ \\
\hline $\begin{array}{c}\mathrm{HCl} \\
7.0 \mathrm{meq} / \mathrm{kg} \\
\text { no } \mathrm{NaCl}\end{array}$ & $\begin{array}{l}\text { Control } \\
\text { Exp. }\end{array}$ & $\begin{array}{l}23.3 \pm 0.3 \\
14.7 \pm 0.4\end{array}$ & $\begin{array}{l}38 \pm 1.4 \\
51 \pm 0.8\end{array}$ & $\begin{array}{l}37 \pm 1.2 \\
31 \pm 0.6\end{array}$ & $\begin{array}{l}147 \pm 0.4 \\
145 \pm 0.7\end{array}$ & $\begin{array}{l}3.9 \pm 0.1 \\
3.4 \pm 0.2\end{array}$ & $\begin{array}{l}109 \pm 1.3 \\
119 \pm 1.5\end{array}$ \\
\hline $\begin{array}{c}\mathrm{HCl} \\
3.5 \mathrm{meq} / \mathrm{kg} \\
\text { no } \mathrm{NaCl}\end{array}$ & $\begin{array}{l}\text { Control } \\
\text { Exp. }\end{array}$ & $\begin{array}{l}23.0 \pm 0.5 \\
19.3 \pm 0.9\end{array}$ & $\begin{array}{l}39 \pm 1.2 \\
43 \pm 0.9\end{array}$ & $\begin{array}{l}38 \pm 1.7 \\
34 \pm 1.1\end{array}$ & $\begin{array}{l}149 \pm 0.8 \\
148 \pm 0.6\end{array}$ & $\begin{array}{l}3.9 \pm 0.1 \\
3.7 \pm 0.0\end{array}$ & $\begin{array}{l}110 \pm 0.6 \\
116 \pm 1.5\end{array}$ \\
\hline $\begin{array}{c}\mathrm{H}_{2} \mathrm{SO}_{4} \\
7.0 \mathrm{meq} / \mathrm{kg} \\
\text { no } \mathrm{NaCl}\end{array}$ & $\begin{array}{l}\text { Control } \\
\text { Exp. }\end{array}$ & $\begin{array}{l}23.3 \pm 0.3 \\
19.6 \pm 0.4\end{array}$ & $\begin{array}{l}38 \pm 0.6 \\
45 \pm 1.5\end{array}$ & $\begin{array}{l}37 \pm 0.4 \\
37 \pm 0.6\end{array}$ & $\begin{array}{l}147 \pm 0.4 \\
142 \pm 1.1\end{array}$ & $\begin{array}{l}3.9 \pm 0.1 \\
3.2 \pm 0.1\end{array}$ & $\begin{array}{l}109 \pm 0.8 \\
108 \pm 1.2\end{array}$ \\
\hline $\begin{array}{c}\mathrm{HNO}_{3} \\
7.0 \mathrm{meq} / \mathrm{kg} \\
\text { no } \mathrm{NaCl}\end{array}$ & $\begin{array}{l}\text { Control } \\
\text { Exp. }\end{array}$ & $\begin{array}{l}22.8 \pm 0.6 \\
24.9 \pm 1.1\end{array}$ & $\begin{array}{l}38 \pm 0.2 \\
39 \pm 1.2\end{array}$ & $\begin{array}{l}37 \pm 1.2 \\
40 \pm 1.8\end{array}$ & $\begin{array}{l}149 \pm 0.9 \\
131 \pm 1.9\end{array}$ & $\begin{array}{l}3.9 \pm 0.1 \\
2.3 \pm 0.1\end{array}$ & $\begin{array}{r}111 \pm 1.0 \\
70 \pm 3.5\end{array}$ \\
\hline
\end{tabular}

Bloods were drawn for analysis at the end of each balance day before daily acid feeding. All data are shown as mean $\pm \mathrm{SEM}$.

Urine $\mathrm{pH}$ fell in all eight groups by approximately $0.5 \mathrm{pH}$ units. The rise in urinary net acid excretion was due almost exclusively to an increase in ammonium ex-

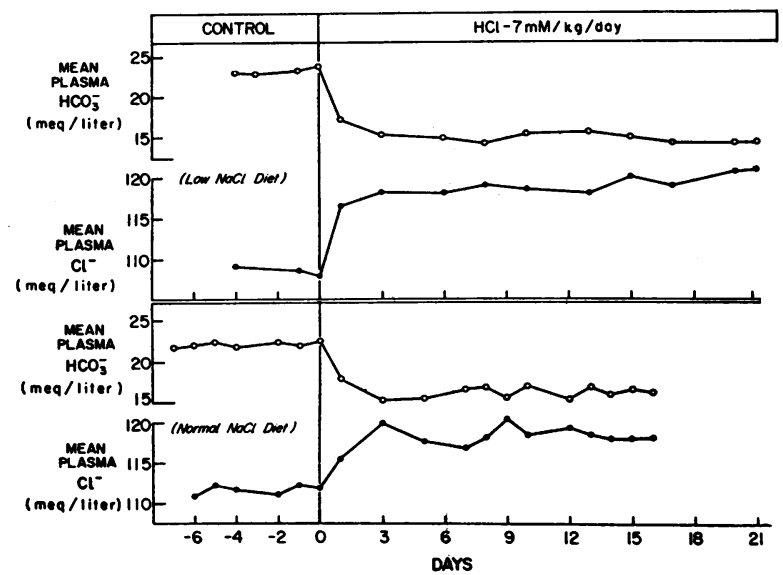

Figure 1 Mean response of plasma bicarbonate and chloride concentrations in dogs chronically fed $7 \mathrm{mM} / \mathrm{kg} /$ day of $\mathrm{HCl}$ while ingesting either a low $-\mathrm{NaCl}$ diet (upper half of figure) or a normal $\mathrm{NaCl}$ diet (lower half of figure). cretion, titrable acid excretion remaining virtually constant.

\section{Effect of hydrochloric acid in dogs ingesting either a normal or a low $\mathrm{NaCl}$ diet}

\section{Plasma Data for Groups Given 7.0 mM of $\mathrm{HCl}$ /} KG/DAY (TABLE III).

In both normal and low $\mathrm{NaCl}$ studies, plasma $\left[\mathrm{HCO}_{8}{ }^{-}\right]$ declined to its nadir within 3 days and thereafter was virtually constant (Fig. 1) ; the slope (i.e., the change in plasma $\left[\mathrm{HCO}_{3}^{-}\right]$over time) for the period from day 3 to the end of the study was not significantly different from zero.

As shown in Figs. 2 and 3, delta plasma $\left[\mathrm{HCO}_{3}^{-}\right]$for the normal and low $\mathrm{NaCl}$ groups at day 3 and during the steady-state phase of the acid-feeding period were -6.6 and $-6.2 \mathrm{meq} /$ liter (normal $\mathrm{NaCl}$ group) and -8.1 and $-8.6 \mathrm{meq} /$ liter (low $\mathrm{NaCl}$ group) respectively. The mean values for each group are significantly different from zero. However, within each group the values for day 3 and the steady state are not significantly different. The steady-state values, as well as the day 3 
Day 3
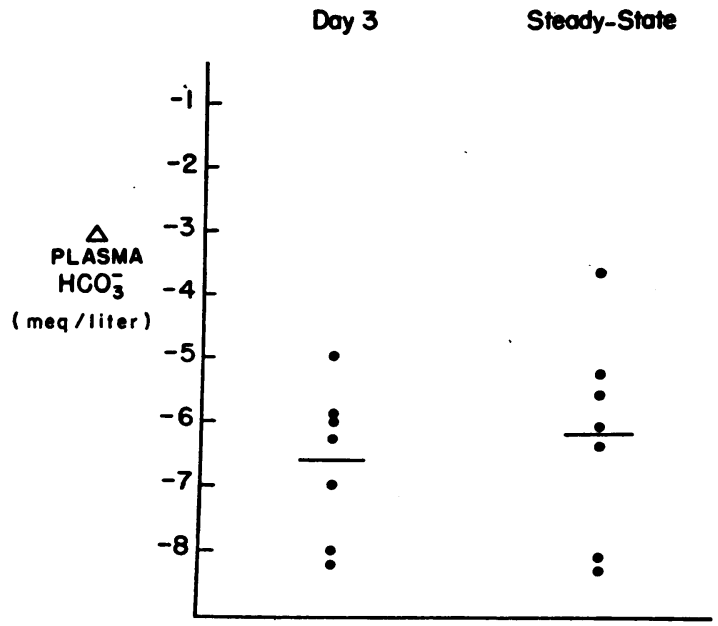

FIGURE 2 Delta plasma bicarbonate concentration at day 3 and during the steady-state in animals chronically receiving $7 \mathrm{mM} / \mathrm{kg} /$ day of $\mathrm{HCl}$ and a normal $\mathrm{NaCl}$ diet.

values, are not significantly different in the low and normal $\mathrm{NaCl}$ groups. The steady-state values for the other plasma electrolytes were as follows: mean delta plasma $\left[\mathrm{H}^{+}\right]$was +13 neq/liter for the low $\mathrm{NaCl}$ group and +10 neq/liter for the normal $\mathrm{NaCl}$ group; both values are significantly different from zero but not from each other. Plasma $\left[\mathrm{Na}^{+}\right]$did not change appreciably. Plasma $\left[\mathrm{Cl}^{-}\right]$rose $10.4 \mathrm{meq} /$ liter in the low $\mathrm{NaCl}$ group and $7.2 \mathrm{meq} /$ liter in the normal $\mathrm{NaCl}$ group ; both values are significantly different from zero but not from each

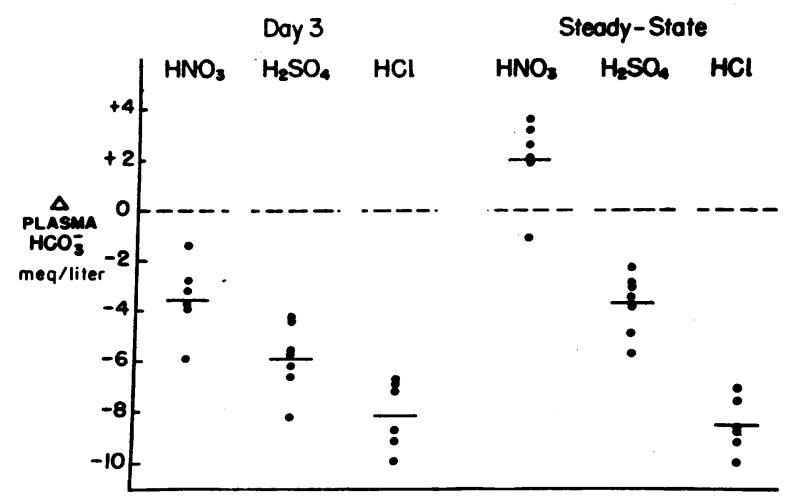

Figure 3 Effect of $7 \mathrm{meq} / \mathrm{kg} /$ day of $\mathrm{H}^{+}$on delta plasma bicarbonate concentration at day 3 and during the steady state in animals receiving $\mathrm{HNO}_{3}, \mathrm{H}_{2} \mathrm{SO}_{4}$, or $\mathrm{HCl}$, and a low- $\mathrm{NaCl}$ diet.

other. Plasma $\left[\mathrm{K}^{+}\right]$fell by $0.5 \mathrm{meq} /$ liter in the low $\mathrm{NaCl}$ group and by $0.8 \mathrm{meq} / \mathrm{liter}$ in the normal $\mathrm{NaCl}$ group; these values are significantly different from zero but not from each other.

To examine more rigorously the possible influence of the level of $\mathrm{NaCl}$ intake on plasma bicarbonate concentration during the feeding of $7 \mathrm{mM} / \mathrm{kg}$ /day of $\mathrm{HCl}$, an additional 12 studies were carried out in animals ingesting a normal $\mathrm{NaCl}$ diet and an additional 15 studies in animals ingesting a low $\mathrm{NaCl}$ diet. A comparison of the total group of normal $\mathrm{NaCl}$ studies (numbering 19) with the total group of low $\mathrm{NaCl}$ studies (numbering 21) indicated no significant influence of $\mathrm{NaCl}$ intake on acid-

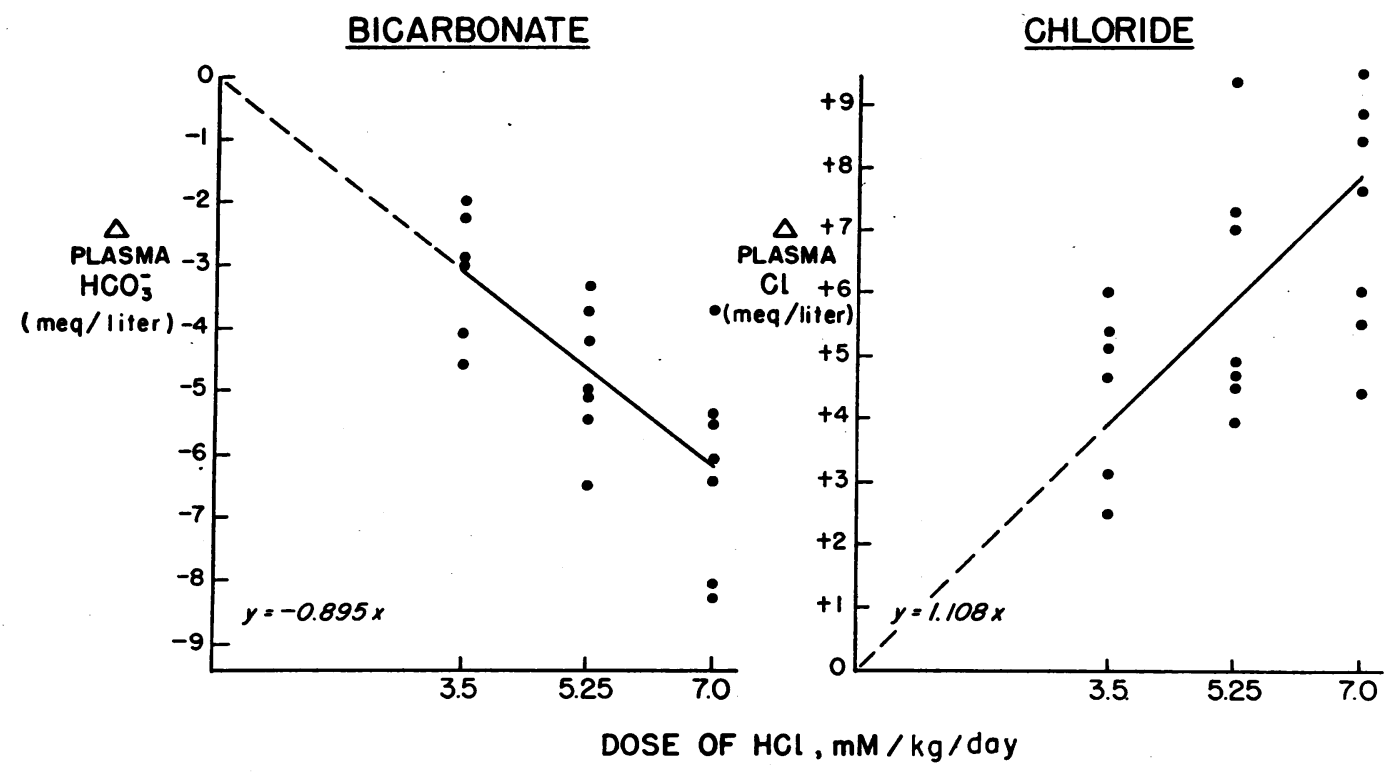

Figure 4 Effect of graded doses of $\mathrm{HCl}$ on steady-state plasma bicarbonate (left side) and chloride (right side) concentrations in animals receiving a normal $\mathrm{NaCl}$ intake. For detailed discussion, see text. 


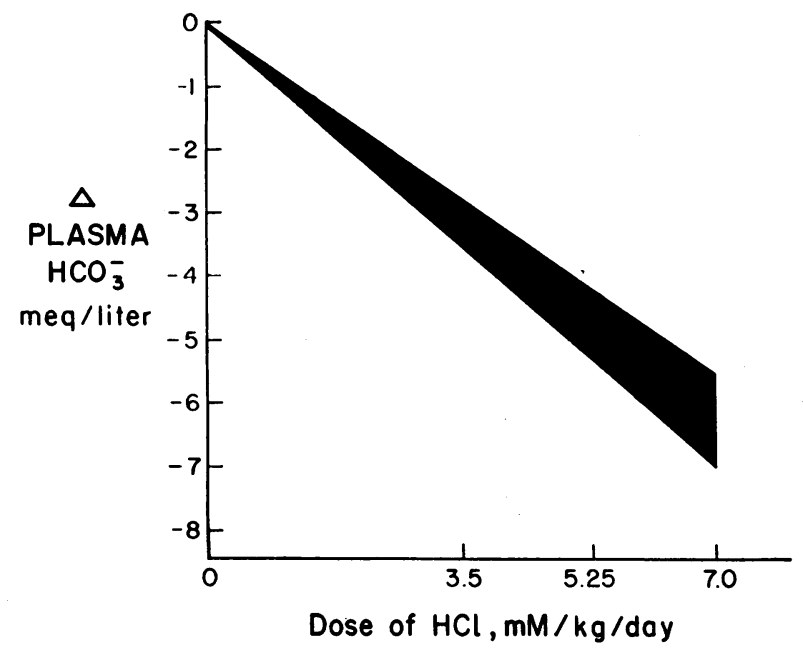

Figure $595 \%$ confidence interval for the slope of the curve relating dose of $\mathrm{HCl}$ to delta plasma bicarbonate concentration. The band defines (with a $95 \%$ probability) the range within which the slope of a new response curve obtained in any population of normal dogs would be expected to lie. The data from which this confidence interval was derived are shown in Fig. 4 and the statistical methods used in the calculation are described in the text.

base balance. In the normal $\mathrm{NaCl}$ group, mean plasma [ $\mathrm{HCO}_{3}{ }^{-}$] fell from 21.6 to $14.7 \mathrm{meq} /$ liter, a difference of $6.9 \pm 0.4 \mathrm{meq} /$ liter. In the low $\mathrm{NaCl}$ group, mean plasma [ $\mathrm{HCO}_{3}{ }^{-}$] fell from 22.6 to $14.6 \mathrm{meq} /$ liter, a difference of $8.0 \pm 0.4 \mathrm{meq} /$ liter.

Cumulative Balance Data at Days 3 and 15 for Groups Given $7.0 \mathrm{MM}$ of $\mathrm{HCl} / \mathrm{Kg} / \mathrm{day}$ (Table II).

The electrolyte balances at day 3 were as follows: average cumulative $\mathrm{Na}^{+}$balance was $-13 \mathrm{meq}$ for the low $\mathrm{NaCl}$ group and -9 meq for the normal $\mathrm{NaCl}$ group; these values are not significantly different from zero or from each other. Average cumulative $\mathrm{K}^{+}$balance was -53 meq for the low $\mathrm{NaCl}$ group and -49 meq for the normal $\mathrm{NaCl}$ group. Average cumulative $\mathrm{K}_{\mathrm{N}}$ balance ( $\mathrm{K}$ balance corrected for $\mathrm{N} ; 2.7 \mathrm{meq} / \mathrm{K}^{+} / \mathrm{gN}$ ) was -57 meq for the low $\mathrm{NaCl}$ group and -52 meq for the normal $\mathrm{NaCl}$ group. The $\mathrm{K}^{+}$and $\mathrm{K}_{\mathrm{N}}$ values are significantly different from zero but not from each other. Average cumulative $\mathrm{Cl}^{-}$balance was $+90 \mathrm{meq}$ for the low $\mathrm{NaCl}$ group and +66 meq for the normal $\mathrm{NaCl}$ group; both values are significantly different from zero but not from each other.

During the additional studies described above, sodium balances were carried out in the majority of the animals during the first 3 days of acid feeding, and the data from the initial group and the supplementary group of studies were combined for statistical analysis. The mean delta cumulative sodium balance for the total of 19 normal $\mathrm{NaCl}$ dogs was $-13 \mathrm{meq}$ and for the 14 low$\mathrm{NaCl}$ dogs was -7 meq. The former value is significantly different from zero at the 0.05 level and the latter value significantly different from zero at the 0.01 level; the values were not significantly different from each other. Sodium, potassium, and chloride balances did not change significantly between days 3 and 15 .

Relationship Between Dose of $\mathrm{HCl}$ and Changes in Plasma and Urine Composition in Animals Receiving a Normal $\mathrm{NaCl}$ Intake.

Bicarbonate, hydrogen ion, and chloride response curves. The left-hand portion of Fig. 4 depicts the steady-state delta plasma $\left[\mathrm{HCO}^{-}\right]$at three different levels of acid intake $(3.5,5.25$, and $7.0 \mathrm{mM} / \mathrm{kg} /$ day $)$. Plasma $\left[\mathrm{HCO}^{-}\right]$during the control period did not differ significantly among the three groups and averaged $22.0 \pm 0.2 \mathrm{meq} /$ liter. The relationship between steady-
A. $\mathrm{H}^{+}$Regression Curve

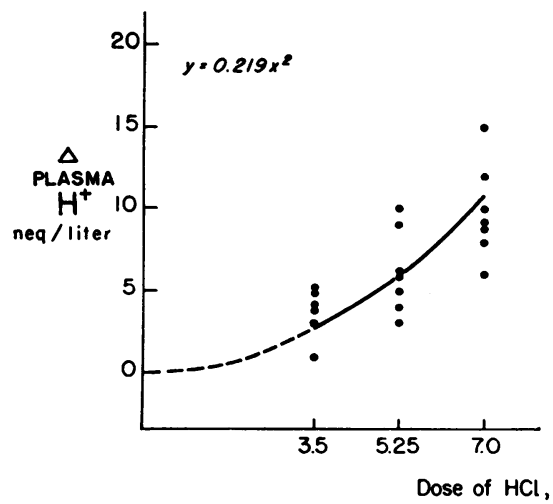

B. $\mathrm{K}^{+}$Regression Curve

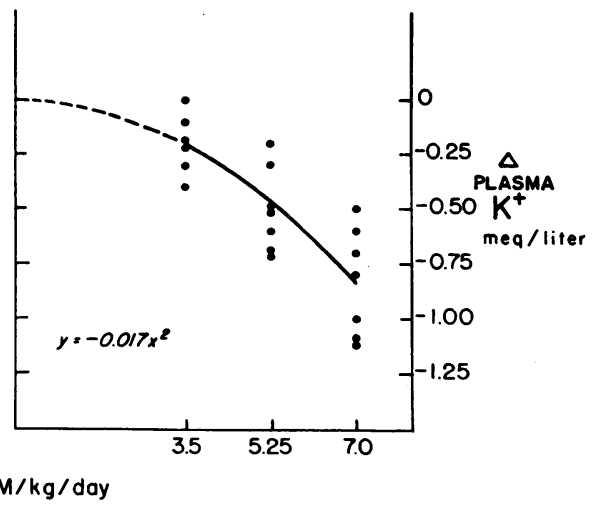

Figure 6 Effect of graded doses of $\mathrm{HCl}$ on steady-state delta plasma hydrogen ion (left side) and potassium (right side) concentrations. 
state delta plasma $\left[\mathrm{HCO}_{3}^{-}\right]$and the acid load, by the method of least squares, was found to be defined by the expression $y=-0.895 x(P<0.01)$; this expression was not improved by the addition of a quadratic term.

Fig. 5 shows the $95 \%$ confidence interval for the slope of the mean response curve. It is noteworthy that the extreme slopes as defined by this band vary between only -1.0 and -0.80 and that at the widest point of the band (acid load of $7 \mathrm{mM} / \mathrm{kg} /$ day) the plasma $\left[\mathrm{HCO}_{3}{ }^{-}\right]$ varies by only $1.5 \mathrm{meq} /$ liter. This readily reproducible and narrow confidence band thus should provide a useful framework for further investigation of acid-base regulation.

The left-hand portion of Fig. 6 depicts the relationship between steady-state delta plasma $\left[\mathrm{H}^{+}\right]$and acid load. This relationship is best defined by the quadratic regression, $y=0.219 x^{2}$.

The relationship between dose of acid administered and the reduction in plasma bicarbonate concentration in the low $\mathrm{NaCl}$ studies was similar to that in the normal $\mathrm{NaCl}$ group ; the decrement in average plasma $\left[\mathrm{HCO}_{3}{ }^{-}\right]$ for the $3.5 \mathrm{mM} / \mathrm{kg} /$ day group was $-3.7 \mathrm{meq} / \mathrm{liter}$, compared with $-8.6 \mathrm{meq} /$ liter for the group receiving 7.0 $\mathrm{mM} / \mathrm{kg} /$ day.

The right-hand portion of Fig. 4 depicts the steadystate delta plasma $\left[\mathrm{Cl}^{-}\right]$at the three levels of acid intake $(3.5,5.25$ and $7.0 \mathrm{mM} / \mathrm{kg} /$ day $)$. Plasma $\left[\mathrm{Cl}^{-}\right]$ during the control period did not differ significantly among the three groups and averaged $111.1 \pm 0.4 \mathrm{meq} /$ liter. The relationship between steady-state delta plasma $\left[\mathrm{Cl}^{-}\right]$and the acid load, by the method of least squares, was defined by the expression, $y=1.108 x(P<0.01)$; the test for deviations from linearity was nonsignificant.

Balance data and changes in plasma $\left[\mathrm{Na}^{+}\right]$and $\left[\mathrm{K}^{+}\right]$. Plasma $\left[\mathrm{Na}^{+}\right]$did not change appreciably in any group. Plasma $\left[\mathrm{K}^{+}\right]$during the control period averaged $3.9 \mathrm{meq} /$ liter and did not differ significantly among the groups. In the acid-feeding period, plasma $\left[\mathrm{K}^{+}\right]$fell, reaching its nadir between day 3-8, and remained unchanged thereafter. The right-hand portion of Fig. 6 is a plot of the steady-state delta plasma $\left[\mathrm{K}^{+}\right]$at the three levels of acid intake. The best fitting line defining the relationship between delta plasma $\left[\mathrm{K}^{+}\right]$and the acid load was the quadratic regression, $y=0.017 x^{2}$.

The percent of $\mathrm{H}^{+}$and $\mathrm{Cl}^{-}$recovered over the first 15 days of study was virtually identical in all three groups, varying between 81 and $88 \%$ for hydrogen and between 94 and $95 \%$ for chloride (Table II). Analyses of the $\mathrm{Na}^{+}$and $\mathrm{Cl}^{-}$balances at 15 days revealed no significant dose-dependent changes. However, average cumulative $\mathrm{K}^{+}$loss at 15 days in the $7.0 \mathrm{mM} / \mathrm{kg} /$ day group $(-59)$ meq) was significantly greater than in the two groups receiving lower doses of $\mathrm{HCl}(-15 \mathrm{meq}$ and -23

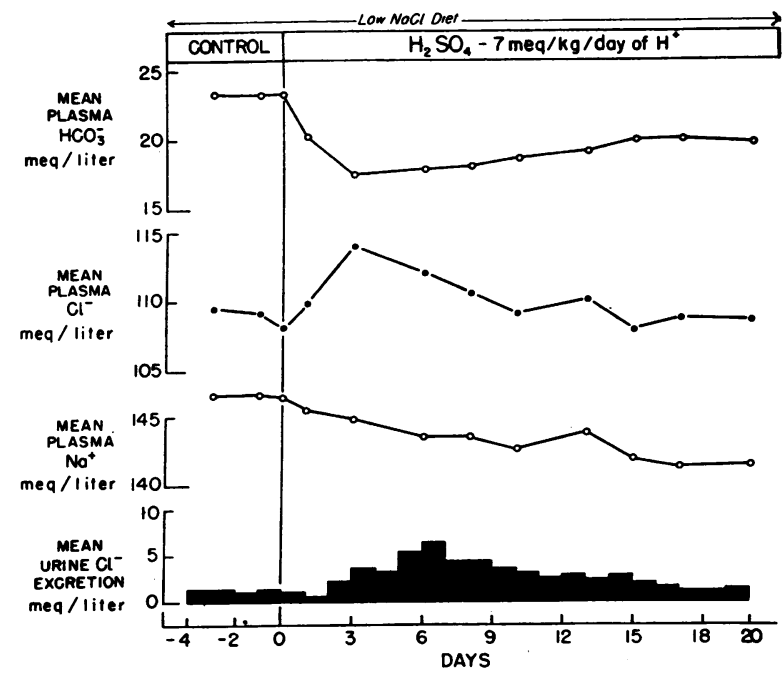

FigURE 7 Mean response of plasma bicarbonate, chloride, and sodium concentrations, and of urine chloride excretion in dogs given $7 \mathrm{meq} / \mathrm{kg} /$ day of $\mathrm{H}^{+}$as $\mathrm{H}_{2} \mathrm{SO}_{4}$ while ingesting a low- $\mathrm{NaCl}$ diet.

meq). $K_{N}$ balances at day 15 were not significantly different among the 3 groups.

Effect of sulfuric acid ( $7 \mathrm{meq} / \mathrm{kg} /$ day of $\mathrm{H}^{+}$) in dogs ingesting a low $\mathrm{NaCl}$ diet

Plasma Data (Table III).

In dogs receiving $\mathrm{H}_{2} \mathrm{SO}_{4}$, plasma $\left[\mathrm{HCO}_{3}{ }^{-}\right]$declined to its nadir over the first 3 days of study, reaching a value $5.9 \mathrm{meq} /$ liter below control. In contrast to the $\mathrm{HCl}$ studies, a slight upward trend in plasma $\left[\mathrm{HCO}^{-}\right]$was observed between days 3 and 15 (Fig. 7). Between days 15 and 21 there was no further change, as evidenced by the fact that the slope of the values for plasma [ $\mathrm{HCO}^{-}$] over this interval was not significantly different from zero. On the basis of these findings; the interval from day 15 to 21 was chosen as the steady state for the $\mathrm{H}_{2} \mathrm{SO}_{4}$ studies.

In the steady-state period, mean delta plasma $\left[\mathrm{HCO}^{-}{ }^{-}\right]$ was $-3.7 \mathrm{meq} /$ liter, a value significantly different from zero. Mean delta plasma $\left[\mathrm{H}^{+}\right]$in the steady-state period was +7 neq/liter, also significantly different from zero. Mean plasma $\left[\mathrm{Na}^{+}\right]$fell by $5.1 \pm 0.8 \mathrm{meq} / \mathrm{liter}$; the decrement developed slowly and progressively during the entire acid-feeding period. Mean plasma $\left[\mathrm{Cl}^{-}\right]$rose by $5.2 \mathrm{meq} /$ liter within 3 days after acid feeding was begun but by the 10th day of acid feeding, plasma $\left[\mathrm{Cl}^{-}\right]$had declined to control levels (delta plasma $\left[\mathrm{Cl}^{-}\right],-0.7$ meq/liter). Mean plasma $\left[\mathrm{K}^{+}\right]$fell significantly by 0.7 meq/liter. 


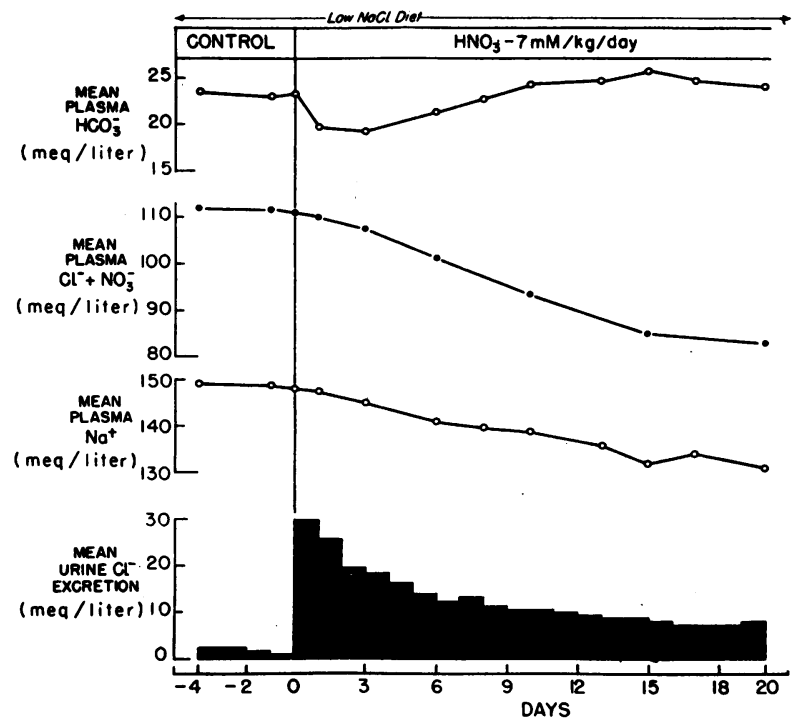

Figure 8 Mean response of plasma bicarbonate, of chloride plus nitrate, of sodium concentrations and also of urine chloride excretion in dogs given $7 \mathrm{mM} / \mathrm{kg} /$ day of $\mathrm{HNO}_{3}$ while ingesting a low- $\mathrm{NaCl}$ intake.

\section{Cumulative Balance Data at Days 3} AND 15 (TABLE II)

Average cumulative $\mathrm{Na}^{+}$balance was $-45 \mathrm{meq}$ at 3 days and $-66 \mathrm{meq}$ at 15 days of acid feeding (each value significantly different from zero but not from each other). Average cumulative $\mathrm{Cl}^{-}$balance was -1 meq at 3 days and -28 meq at 15 days of acid feeding. These values are significantly different from one another and the latter value is significantly different from zero. Average cumulative $\mathrm{K}^{+}$balance was $-65 \mathrm{meq}$ at 3 days and $-94 \mathrm{meq}$ at 15 days of acid feeding; both values are significantly different from zero but not from each other. Average cumulative $\mathrm{K}_{\mathrm{N}}$ balance was -57 meq at 3 days and $-54 \mathrm{meq}$ at 15 days of acid feeding; both values are significantly different from zero but not from each other.

Effect of nitric acid $(7 \mathrm{mM} / \mathrm{kg} /$ day $)$ in dogs ingesting a low $\mathrm{NaCl}$ diet

Plasma Data (Table III).

Plasma $\left[\mathrm{HCO}^{-}\right]$fell to its nadir over the first 3 days of acid-feeding, reaching a value $3.5 \mathrm{meq} /$ liter below control. Over the next 10-12 days, there was a significant rise that restored plasma bicarbonate concentration to normal (Fig. 8). Statistical analysis of the data from days 15 to 21 reveal that the slope was negative and significantly different from zero; however, since the absolute value was quite small, $(-0.3 \mathrm{meq} / \mathrm{day})$, we chose the period from days 15 to 21 as the closest approximation to a steady-state for this group.
Mean delta plasma $\left[\mathrm{HCO}_{s}^{-}\right]$in the steady state was $+2.1 \mathrm{meq} / \mathrm{liter}$, a figure not significantly different from zero; it should be noted, however, that plasma $\left[\mathrm{HCO}_{3}^{-}\right.$] actually rose above control in five of six animals. Mean delta plasma $\left[\mathrm{H}^{+}\right]$in the steady state was +1 neq/liter, a value not significantly different from zero. Mean plasma $\left[\mathrm{Na}^{+}\right]$fell progressively through the acid feeding period to a value $17.5 \mathrm{meq} / \mathrm{liter}$ below control. Mean plasma $\left[\mathrm{K}^{+}\right]$declined $1.6 \mathrm{meq} /$ liter, most of the change occurring during the first 3-4 days of acid administration. Mean plasma $\left[\mathrm{Cl}^{-}\right]$fell by $40.5 \mathrm{meq} /$ liter and mean plasma nitrate concentration simultaneously rose from 0.8 to $15.1 \mathrm{meq} /$ liter. The net result was that the sum of chloride plus nitrate (total reabsorbable anion [10]) fell by $25.9 \mathrm{meq} /$ liter. The anion gap (as calculated from $\left.\left[\mathrm{Na}^{+}+\mathrm{K}^{+}\right]-\left[\mathrm{Cl}^{-}+\mathrm{NO}_{s}^{-}+\mathrm{HCO}^{-}\right]\right)$rose by approximately $5 \mathrm{meq} /$ liter, a finding similar to that previously observed during the alkalosis induced by sodium nitrate infusion (10).

\section{Cumulative Balance Data at Days 3 AND 15 (TABLE II)}

Average cumulative $\mathrm{Na}^{+}$balance was -64 meq at 3 days and -153 meq at 15 days of acid feeding. Average cumulative $\mathrm{K}^{+}$balance was -85 meq at 3 days and $-171 \mathrm{meq}$ at 15 days; average cumulative $\mathrm{K}_{\mathrm{N}}$ balance was -94 meq and -145 meq for the same periods. The $\mathrm{Na}^{+}, \mathrm{K}^{+}$, and $\mathrm{K}_{\mathrm{N}}$ values at days 3 and 15 are significantly different from zero; they are also significantly different from each other $\left(\mathrm{K}_{\mathrm{N}}\right.$ and $\mathrm{Na}^{+}$at the 0.02 level). Average cumulative $\mathrm{Cl}^{-}$balance was -69 meq and -197 meq at 3 and 15 days respectively; these values are significantly different from zero and from each other.

Some pertinent cross-comparisons of the grouns given 7 meq of $\mathrm{H}^{+} / \mathrm{kg} /$ day as either $\mathrm{HCl}, \mathrm{H}_{2} \mathrm{SO}_{4}$, or $\mathrm{HNO}_{3}$ while ingesting a low- $\mathrm{NaCl}$ diet

\section{Plasma Data}

Fig. 3 shows delta plasma $\left[\mathrm{HCO}_{3}{ }^{-}\right]$at day 3 (left side) and during the steady-state phase (right side) of the acid-feeding period in the animals given $7 \mathrm{meq}$ of $\mathrm{H}^{+} / \mathrm{kg} /$ day of one of the three acids while receiving a low $\mathrm{NaCl}$ diet. Analysis of variance demonstrated that the values in the three groups are significantly different from one another both at day 3 (at the 0.02 level) and during the steady state.

\section{Cumulative Balance Data}

The electrolyte balances at day 3 were as follows: average cumulative $\mathrm{Na}^{+}$balance was: $\mathrm{HCl},-13$ meq; $\mathrm{H}_{2} \mathrm{SO}_{4}$. $-45 \mathrm{meq}$; and $\mathrm{HNO}_{3},-64$ meq; mean values for the $\mathrm{H}_{2} \mathrm{SO}_{4}$ and $\mathrm{HNO}_{3}$ groups were significantly larger than the mean value for the $\mathrm{HCl}$ group. $\mathrm{K}^{+}$bal- 
ance ranged between -53 and -85 meq for the three groups; there were no significant differences among the groups. Average cumulative $\mathrm{Na}^{+}+\mathrm{K}^{+}$balance on a low- $\mathrm{NaCl}$ diet for the first three days was $-66 \mathrm{meq}$ in the $\mathrm{HCl}$ group compared to -110 meq for the $\mathrm{H}_{2} \mathrm{SO}$. group and -148 meq for the $\mathrm{HNO}_{3}$ group; the values for the $\mathrm{H}_{2} \mathrm{SO}_{4}$ and $\mathrm{HNO}_{3}$ groups were significantly larger than the value for the $\mathrm{HCl}$ group. Comparable data at day 15 are shown in Table II.

Plasma phosphate, sulfate and hematocrit values were not appreciably altered from control in any group during the entire study. Plasma creatinine values were not significantly different from control in any group during the entire course of each study.

\section{DISCUSSION}

The present study indicates that the hydrogen ion load cannot be invoked as the major factor determining the level of plasma bicarbonate concentration during chronic administration of a mineral acid. This conclusion is based on the finding that dogs given large doses of hydrochloric acid $(7 \mathrm{mM} / \mathrm{kg} /$ day) while ingesting a low- $\mathrm{NaCl}$ diet show reductions in plasma bicarbonate concentration that are significantly greater than those seen in dogs given equivalent quantities of $\mathrm{H}^{+}$as nitric or sulfuric acid. Thus, after three days of acid feeding (a time at which bicarbonate concentration had reached its nadir) the plasma bicarbonate concentration in animals receiving hydrochloric acid had fallen by 8.1 meq/liter, whereas bicarbonate concentration in dogs receiving sulfuric or nitric acids had fallen significantly less, by only 5.9 and $3.5 \mathrm{meq} /$ liter, respectively. These differences became even more striking during the succeeding 1-2 wk of acid feeding, bicarbonate concentration in animals receiving hydrochloric acid remaining at its nadir but the concentration rising significantly in both the sulfuric and nitric acid groups. As a result the steady-state values for plasma bicarbonate, relative to control, were $-8.6 \mathrm{meq} /$ liter for $\mathrm{HCl},-3.7 \mathrm{meq} / \mathrm{liter}$ for $\mathrm{H}_{2} \mathrm{SO}_{4}$, and $+2.1 \mathrm{meq} /$ liter for $\mathrm{HNO}_{3}$ (Fig. 3), each value significantly different from the others. These findings appear to exclude the possibility that the major stimulus to increased hydrogen excretion during administration of a mineral acid is a change in systemic acidbase balance.

On the basis of our data, we suggest that hydrogen ion secretion during acid loading is governed by fundamentally the same factors that govern acid secretion and bicarbonate reabsorption in metabolic alkalosis. Recent. studies indicate that in metabolic alkalosis two, and only two, factors are responsible for the increase in hydrogen ion secretion; first, the delivery of sodium to distal ex- change sites ${ }^{2}$ with an anion other than one derived from dietary or endogenous acids, and second, a stimulus to distal sodium-cation exchange greater than that provided by a low-sodium diet alone $(4,5)$. The way in which these two factors interact to produce metabolic alkalosis is well illustrated by the response of the kidneys to the gastric drainage of hydrochloric acid (2-4). As bicarbonate replaces chloride in the glomerular filtrate, the capacity of the proximal tubule to reabsorb bicarbonate is exceeded and the excess bicarbonate is delivered with sodium to exchange sites. Because a low sodium intake per se does not stimulate distal sodium exchange sufficiently to allow full conservation of the extra sodium load, and because potassium is readily available for exchange with that portion of sodium that is conserved, only part of the sodium increment is reabsorbed in exchange for hydrogen. As a result there is a considerable loss of cation into the urine with bicarbonate. However, as the sodium loss and concomitant contraction of extracellular fluid stimulate sodium reabsorption, and as the depletion of tubular potassium stores reduces the availability of this cation for exchange, sodium-hydrogen exchange is enhanced and sustained metabolic alkalosis develops.

The same basic mechanisms appear to account for the response of the alkalotic subject fed a hydrogen ion load in association with a poorly reabsorbable anion (7). Given the increased delivery of sodium to distal exchange sites produced by the anion load, and given the marked avidity for sodium already present in the alkalotic subject, sodium-hydrogen exchange and acid excretion increase despite the persistent elevation of both plasma bicarbonate concentration and $\mathrm{pH}$. The rise in acid excretion and in plasma bicarbonate concentration seen in cation-depleted $\mathrm{dog}$ and man given sodium or potassium sulfate can be well explained in the same fashion $(4,11,12)$.

The present study indicates that the fundamental mechanisms responsible for the increased secretion of hydrogen during mineral acid loading in the dog are the same as in metabolic alkalosis. It appears that for the kidney to remove a mineral acid load, two and only two conditions must be satisfied; first, sodium previously reabsorbed in proximal portions of the nephron must be delivered to exchange sites in quantities equal to ingested hydrogen, and second, a stimulus to sodium-cation exchange greater than that provided by a low-salt diet must be present.

Against this background we can now turn to a detailed consideration of the changes observed with the three

\footnotetext{
2 The term "exchange" as used in this paper, does not imply fixed coupling of cation transport, but rather the facilitation of potassium and hydrogen excretion by increased distal sodium delivery.
} 
mineral acids, begining with hydrochloric acid. As has long been known, during $\mathrm{HCl}$ adiministration there is an initial loss of sodium and potassium accompanied by a progressive rise in acid excretion, plasma bicarbonate concentration reaching its nadir after several days (1317). The usual interpretation of these findings is that acidosis stimulates the kidney to increase acid excretion and that the inability of the kidney to increase rapidly the production of free base, ammonia, accounts for the transient phase in which sodium and potassium are lost in the urine in association with administered chloride. Our data suggest a different interpretation, as follows: when $\mathrm{HCl}$ is administered, the chloride increment is presented to the kidney with sodium formerly reabsorbed with bicarbonate. For hydrogen to be excreted in an amount equal to ingested hydrogen, all of this sodium must be delivered with chloride to distal exchange sites. However, because chloride is a highly reabsorbable anion, there is an initial retention of chloride that denies the distal tubule access to sodium in amounts equal to ingested hydrogen. As a result, hyperchloremia, retention of hydrogen, and a reduction in plasma bicarbonate concentration occur. However, as chloride retention elevates plasma chloride concentration, ever larger quantities of chloride escape reabsorption, carrying sodium previously reabsorbed in the proximal tubule and loop of Henle to the distal nephron. Thus, the quantity of sodium delivered to distal exchange sites ultimately reaches a level equal to hydrogen intake.

Although this sequence of events removes the primary constraint on excretion of the acid load, increased delivery of sodium is not in itself sufficient to fully augment acid excretion, because a low-sodium diet does not provide a stimulus to distal transport mechanisms powerful enough to effect full conservation of the sodium load. Moreover, some portion of the sodium that is conserved exchanges with potassium instead of with hydrogen. Thus, just as in metabolic alkalosis, only after there is a loss of sodium, as well as some depletion of potassium stores, can all additional sodium arriving from the proximal portions of the nephron be conserved by exchange with hydrogen and can a new steady state of acidbase balance be achieved.

The situation with sulfuric acid is quite different because, in contrast with hydrochloric acid, there is no constraint on delivery of administered anion to exchange sites; all administered anion (and accompanying sodium) completely escapes reabsorption in the proximal tubule and loop of Henle, and is delivered promptly to the distal nephron. Thus, the ability of the distal nephron to accelerate sodium-hydrogen exchange is the sole determinant of the amount of hydrogen that can be excreted and therefore of the degree of acidosis that will occur. Obvi- ously this second constraint (i.e. a limit on rate of acceleration of distal hydrogen ion secretion) is present regardless of the character of the administered anion and is responsible for a significant retention of hydrogen before the loss of sodium and potassium leads to full acceleration of sodium-hydrogen exchange. As a result, during sulfuric acid administration there was an initial fall in plasma bicarbonate concentration of $5.9 \mathrm{meq} /$ liter. As a further consequence of the cation loss there was a contraction of extracellular fluid and a rise in plasma chloride concentration of a magnitude almost equal to the fall in the plasma bicarbonate concentration. $^{3}$

The behavior of the kidney after the initial fall in bicarbonate concentration induced by sulfuric acid further illuminates the interplay of anion reabsorbability and acid-base equilibrium. As pointed out above, the sulfuric acid animals, because of the initial contraction of the extracellular fluid, developed over the first 3 days of acid administration a picture of hyperchloremic acidosis indistinguishable from that produced by a moderate dose of $\mathrm{HCl}$. As a result, over the succeeding 7-10 days there was a slight leak of chloride into the urine (and presumably a concomitant loss of hydrogen too small to detect by the balance technique) that accounted for the rise in plasma bicarbonate concentration to a final steady-state value only $3.7 \mathrm{meq} /$ liter below control. The failure of these animals to correct the metabolic acidosis fully, we would postulate, is accounted for by the continued ingestion of sulfuric acid; it seems highly probable that the large filtered load of sulfate enhanced proximal chloride reabsorption (18) and thus precluded full removal of the surplus chloride and hydrogen."

With nitric acid, as with sulfuric, the failure to excrete the acid load during the initial phase of acid feeding was not the result of a limitation on the distal delivery of sodium but rather was the consequence of both an insufficient distal avidity for sodium and of the ready

${ }^{3}$ The loss of sodium (but not of potassium) in the sulfuric acid animals was much larger than in the $\mathrm{HCl}$ animals (Table II). We believe that this finding is accounted for by the fact that animals given sulfuric acid were confronted with a larger load of sodium to be reabsorbed at exchange sites than were the $\mathrm{HCl}$ animals; sulfuric acid animals were faced not only with the standard $7 \mathrm{mM} / \mathrm{kg}$ of proximal sodium reaching the distal tubule with administered anion, but with sodium delivered distally with bicarbonate in quantities considerably larger than in the more acidotic $\mathrm{HCl}$ animals.

* The final chloride concentration, although at control levels, represented a slight but significant hyperchloremia when compared to the reduced serum sodium concentration that developed during prolonged sulfuric acid feeding (Table III). 
availability of potassium for exchange. Nitrate, it will be recalled, is a partially reabsorbable anion that displaces chloride from reabsorption and later is itself delivered into the urine (2). Administration of nitrate, therefore, leads to the delivery of anion and sodium to exchange sites in quantities in excess of administered nitrate, and for this reason the effectiveness of distal sodium-hydrogen exchange is the sole determinant of acid excretion. Thus, during nitric acid administration there was an initial loss of cation, a retention of acid and a contraction of extracellular fluid that led to a rise in the sum of chloride plus nitrate. However, by contrast with sulfuric acid, continued nitric acid ingestion promoted delivery of anion (with sodium) to the distal tubule in excess of administered anion; as a result all of the acid retained originally was removed by sodiumhydrogen exchange and the concentration of bicarbonate in the plasma was restored to normal. ${ }^{5}$

Thus, with nitrate, as with sulfate and chloride, the entire sequence of changes in acid-base balance can best be accounted for within a theoretical framework that does not invoke as a controlling factor either the hydrogen ion load or a change in systemic acid-base balance.

Influence of sodium chloride intake on the response to hydrochloric acid administration. The data demonstrate that the level of sodium chloride intake does not influence the way in which the dog responds to the administration of $\mathrm{HCl}$. Animals ingesting a high-salt diet show a reduction in plasma bicarbonate concentration virtually identical to that seen in those ingesting a low-salt diet. Thus, as might be anticipated from our theoretical framework, availability of dietary sodium chloride at distal exchange sites during acid loading did not in itself lead to accelerated sodium-hydrogen exchange or limit the fall in plasma bicarbonate concentration. It is only after a loss of body sodium stores, induced by delivery into the urine of sodium previously reabsorbed in proximal portions of the nephron, that sodium avidity was increased sufficiently to allow full removal of the ingested acid load. It is of particular interest that the loss of sodium in dogs on either a high- or low-salt diet was small and virtually identical. This finding may be accounted for by the fact that the extracellular volume on either a high- or low-salt diet before acid feeding is virtually the same in both groups, i.e. that the slope relating sodium loss to sodium avidity is extremely steep. ${ }^{6}$ Thus, our present studies throw no light on

\footnotetext{
${ }^{5}$ We believe that the continued loss of small quantities of sodium throughout the period of nitric acid feeding is evidence that the capacity of the distal exchange mechanism, even when maximally stimulated by sodium depletion, was exceeded.

${ }^{6}$ When the sodium chloride intake of a normal dog is reduced from $2.5 \mathrm{meq} / \mathrm{kg} /$ day to less than $0.1 \mathrm{meq} / \mathrm{kg} / \mathrm{day}$,
}

whether the magnitude of the sodium loss during administration of a standard hydrochloric acid load to the $\mathrm{dog}$ is a variable directly related to, or is independent of, initial extracellular fluid volume.

We should also point out that although sodium chloride intake had no significant influence on the response of the dog to $\mathrm{HCl}$, it would be expected to influence the response to sulfuric and nitric acids. It is obvious that when dogs are given sodium chloride and, in addition, are given a large hydrogen load with a nonreabsorbable anion, the effect is equivalent to giving part of the hydrogen load as hydrochloric acid. Further studies will be required to examine the complex interplay of forces determining the new steady state of acid-base equilibrium under such experimental circumstances.

\section{ACKNOWLEDGMENTS}

We wish to thank Dr. Jonas H. Ellenberg for his valuable assistance in the statistical analysis of the data.

This study was supported in part by grants HE-00759 and HE-5309 from the National Heart Institute, National Institutes of Health.

\section{REFERENCES}

1. Gulyassy, P. F., C. van Ypersele de Strihou, and W. B. Schwartz. 1962. On the mechanism of nitrate-induced alkalosis. The possible role of selective chloride depletion in acid-base regulation. J. Clin. Invest. 41: 1850.

2. Needle, M. A., G. J. Kaloyanides, and W. B. Schwartz. 1964. The effects of selective depletion of hydrochloric acid on acid-base and electrolyte equilibrium. J. Clin. Invest. $43: 1836$.

3. Kassirer, J. P., and W. B. Schwartz. 1966. The response of normal man to selective depletion of hydrochloric acid. Am. J. Med. 40: 10.

4. Schwartz, W. B., C. van Ypersele de Strihou, and J. P. Kassirer. 1968. Role of anions in metabolic alkalosis and potassium deficiency. N. Engl. J. Med. 279: 630.

5. Seldin, D. W., and F. C. Rector, Jr. 1972. The generation and maintenance of metabolic alkalosis. Kidney Int. 1: 306.

6. Polak, A., G. D. Haynie, R. M. Hays, and W. B. Schwartz. 1961. Effects of chronic hypercapnia on electrolyte and acid-base equilibrium. I. Adaptation. $J$. Clin. Invest. 40: 1223.

7. Tannen, R. L., H. L. Bleich, and W. B. Schwartz. 1966. The renal response to acid loads in metabolic alkalosis. An assessment of the mechanisms regulating acid excretion. J. Clin. Invest. 45: 562.

8. Arbus, G. S., L. A. Hebert, P. R. Levesque, B. E. Etsten, and W. B. Schwartz. 1969. Characterization and clinical application of the "significance band" for acute respiratory alkalosis. N. Engl. J. Med. 280: 117.

9. Ferrari, A. 1960. Nitrogen determination by a continuous digestion and analysis system. Ann. N. Y. Acad. Sci. 87: 792 .

the sodium loss is very small (some 10 to 15 meq) and the change in extracellular volume is therefore trivial. J. J. Cohen, A. Gougoux, W. D. Kaehny, and W. B. Schwartz. Unpublished data. 
10. Berkman, P. M., C. van Ypersele de Strihou, M. A. Needle, P. F. Gulyassy, and W. B. Schwartz. 1967. Factors which determine whether infusion of the sodium salt of an anion will induce metabolic alkalosis in dogs. Clin. Sci. (Oxf.). 33: 517.

11. Bleich, H. L., R. L. Tannen, and W. B. Schwartz. 1966. The induction of metabolic alkalosis by correction of potassium deficiency. J. Clin. Invest. 45: 573.

12. van Ypersele de Strihou, C., and J. Morales-Barria. 1969. The influence of dietary sodium and potassium intake on the genesis of frusemide-induced alkalosis. Clin. Sci. (Oxf.). $37: 859$.

13. Linder, G. C. 1926. The effect of mineral acid on acidbase regulation in health and in nephritis. $Q . J$. Med. $20: 285$.
14. Folling, A. 1929. On the mechanism of ammonium chloride acidosis. Acta Med. Scand. 41: 221.

15. Sartorius, O. W., J. C. Roemmelt, and R. F. Pitts. 1949. The renal regulation of acid-base balance in man. IV. The nature of the renal compensations in ammonium chloride acidosis. J. Clin. Invest. 28: 423.

16. Wood, F. J. Y. 1955. Ammonium chloride acidosis. Clin. Sci. (Oxf.). 14: 81 .

17. Lemann, J., Jr., E. J. Lennon, A. D. Goodman, J. R. Litzow, and A. S. Relman. 1965. The net balance of acid in subjects given large loads of acid or alkali. $J$. Clin. Invest. 44 : 507.

18. Rapoport, S., and C. D. West. 1950. Ionic antagonism: effect of various anions on chloride excretion during osmotic diuresis in the dog. Am. J. Physiol. 162: 668. 